\title{
THE RESEARCH OF ORGANOLEPTIC AND PHYSICO- CHEMICAL INDICATORS OF MARSHMALLOW IN EDIBLE COATING WITH FRUIT POWDERS
}

\author{
V. Kalmazan, A. Chorna \\ National University of Food Technologies
}

\begin{tabular}{l} 
Key words: \\
Marshmallow \\
Edible coating \\
Fruit powders \\
Preservation of freshness \\
Biodegradable packing \\
\hline
\end{tabular}

Article history:

Received 14.05.2018

Received in revised form

01.06 .2018

Accepted 13.06.2018

Corresponding author:

A. Chorna

E-mail:

Anastasia_chernaya@ukr.net

\begin{abstract}
This article presents experimental studies of the advisability of using edible coating as a way of preventing the formation of marshmallow and the possibility of replacing synthetic packaging (full or partial) with biodegradable. Based on the organoleptic, physico-chemical properties (moisture content) and changes in the mass of the samples during storage feasibility and necessity of using edible coating for marshmallow were proved. An edible coating consists of starch, gelatin, glycerol and water (solvent). In order to expand the range of marshmallow, fruit powders (lemon, strawberry and blueberries) were added to the edible coating. The 5-point scale for the organoleptic assessment of the quality of the studied samples of marshmallow was developed. An additional indicator was chewiness, since the edible coating should not be felt when eating marshmallow. The ranking method determined the coefficients of weight of each indicator in the overall organoleptic evaluation. The organoleptic assessment of the quality of marshmallow samples showed that the edible coating does not change organoleptic parameters.

When storing samples during month, humidity of marshmallow without packaging decreased by $44 \%$, and marshmallow with edible coating - by $30 \%$. It has been established that during this period the weight of the product without packaging decreased by $6,3 \%$, edible coating reduced their weight by $4,3 \%$. It saves its properties better during storage with edible cooking with the addition of lemon powder, and the worst sample was with the addition of strawberry. Probably high losses of mass were caused by insufficient dense layers of application of edible coating. It is advisable to state that edible coating contributes to preserving freshness of marshmallow and is an alternative replacement (partial or full) of synthetic packaging.
\end{abstract}

DOI: $10.24263 / 2225-2924-2018-24-3-27$ 


\title{
ДОСЛІДЖЕННЯ ОРГАНОЛЕПТИЧНИХ \\ I ФІЗИКО-ХІМІЧНИХ ПОКАЗНИКІВ ЗЕФІРУ \\ В ЇСТІВНОМУ ПОКРИТТІ 3 ФРУКТОВИМИ ПОРОШКАМИ
}

\author{
В.Б. Калмазан, А.І. Чорна \\ Національний університет харчових технологій
}

У статті наведено експериментальні дослідження доцільності використання їстівного покриття як засобу запобігання черствіння зефіру та можливості заміни синтетичного пакування (повної або часткової) на біодеградабельне. На основі органолептичних, фізико-хімічних показників (масової частки вологи) та зміни маси досліджуваних зразків під час зберігання доведено доцільність і необхідність використання їстівного покриття для зефіру. Розроблено їстівне покриття, яке складається з крохмалю, желатину, глічерину та води (розчинник). 3 метою розиирення асортименту зефіру в їстівне покриття додавали фруктові порошки (лимон, полуниця та чорниия). Запропоновано 5-балову шкалу для органолептичної оцінки якості досліджуваних зразків зефіру. Додатковим показником введено розжовуваність, оскільки їстівне покриття не має відчуватися під час споживання зефіру. Методом ранжування визначено коефіцієнти вагомості кожного показника в загальній органолептичній оцінщі. Органолептична оцінка якості досліджуваних зразків зефіру показала, щэо розроблене їстівне покриття не змінює органолептичні показники.

Через місяџь зберігання зразків вологість зефіру без упаковки зменшилась на 44\%, а зефіру з їстівним покриттям - на 30\%. Встановлено, щзо під час зберігання зефіру протягом місячя маса продукту без упаковки зменшується на 6,3\%, маса зефіру з їстівним покриттям - на 4,3\%. Найкращуе зберігає свої властивості під час зберігання зефір з їтівним покриттям з додаванням лимонного порошку, найгірше - $з$ додаванням полуничного. Можливо, більші втрати маси були зумовлені недостатньо щільним шаром нанесення їстівного покриття. Отюе, доцільно стверджувати, щзо їстівне покриття сприяє збереженню свіжості зефіру $i \epsilon$ альтернативною заміною (частковою або повною) синтетичного пакування.

Ключові слова: зефір, їстівне покриття, фруктові порошки, збереження свіжості, біодеградабельне пакування.

Постановка проблеми. Зефір - це вид цукристих кондитерських виробів, отриманий збиванням фруктово-ягідного пюре 3 цукром і яєчним білком, 3 додаванням у цю суміш будь-якого з формоутворюючих (драглеутворюючих) наповнювачів: пектину, агарового сиропу, желатинової (мармеладної) маси [1]. Як добавки під час виробництва зефіру застосовуються харчові кислоти, есенції, барвники [2].

Завдяки вмісту вуглеводів зефір в обмежених кількостях сприяє розумовій діяльності, а харчові волокна допомагають травленню, спосіб його приготування дає змогу зберегти живими більшість корисних речовин [3]. 
Зефір має щільну піноподібну структуру, для правильного його зберігання краще вибирати прохолодне місце без доступу світла, якщо він не розпакований, а відкритий - перекласти у вакуумний контейнер. Таким чином він може зберігатися до 1,5 місяця.

Перспективним напрямком у харчовій промисловості $\epsilon$ використання харчових покриттів (плівок) з метою збереження харчової цінності продукту. Ще в давні часи у Стародавньому Китаї у XII ст. використовували харчову упаковку (віск) для збереження вологи та пружності товару. У XV ст. в Свропі така технологія отримала спеціальну назву - лардінг - покриття фруктів та овочів шаром воску або сала, що запобігало усиханню продуктів. В Японії застосовували плівку, яку називали йуба - отримували кип'ятінням соєвого молока 3 метою поліпшення зовнішнього вигляду та збереження якості харчових продуктів. Перший патент на створення харчової упаковки було видано у США у XIX ст., коли запропонували загортати м'ясні продукти в желатинову оболонку.

На сьогодні основними плівкоутворюючими компонентами у складі їстівної упаковки є білки, жири, вуглеводи тощо. За харчовою цінністю їх умовно розділяють на засвоювані (на основі білків, жирів, вуглеводів) та незасвоювані (на основі восків, парафінів, камедей тощо) [4].

Більшість кондитерських виробів, наприклад, цукерки вимагають нанесення їстівного покриття, щоб запобігти злипанню, поглинанню вологи, а для шоколаду та інших ліпідовмісних кондитерських виробів - втрати масла. Цукерки часто покриваються кондитерською глазур'ю, шелаком або воском. Цукерки, покриті покриттям на основі кукурудзяного крохмалю та пластифікатора, залишаються сухими навіть в умовах, що викликають поверхневу липкість. Покриття на основі кукурудзяного крохмалю, у складі якого $\epsilon$ етанол, підсихає швидше, ніж кондитерська глазур, і може бути маркованим як комбіноване білкове покриття [5].

Їстівна упаковка відіграє важливу роль під час зберігання, транспортування та збуту харчових продуктів. Актуальним $є$ вивчення плівкоутворюючих покриттів, що створюють модифіковане середовище, обмежуючи перенесення газів, а також є бар'єром для передачі ароматичних сполук, запобігають розвитку гнильної мікрофлори та перенесенню вологи [6; 7].

Мета статті: для визначення можливості заміни синтетичного пакування на біодеградабельне дослідити зефір з розробленим їстівним покриттям.

Матеріали і методи. Об'єктом дослідження були компоненти їстівного покриття та фруктові порошки для його збагачення. Для розширення асортименту зефіру в їстівне покриття додавали фруктові порошки.

У ході експериментального дослідження аналізували зефір «Школярик» ТМ «Жако» (контрольний зразок), виготовлений за ДСТУ ГОСТ 6441-2003 «Вироби кондитерські пастильні. Загальні технічні умови», та зефір з розробленим їстівним покриттям без добавок і з фруктовими порошками (виробник «Diana Naturals»): лимон, полуниця та чорниця.

Їстівне покриття готували розчиненням плівкоутворювачів (крохмаль і желатин), пластифікатора (гліцерин) та розчинника (води) під час нагрівання на магнітній мішалці. Наносили готове їстівне покриття пензлем на всю поверхню зефіру та досліджували органолептичні показники за ДСТУ ГОСТ 6441-2003 
«Вироби кондитерські пастильні. Загальні технічні умови» та фізико-хімічні показники (масову частку вологи) рефрактометричним методом за ДСТУ 4910:2008 «Вироби кондитерські. Методи визначення масових часток вологи та сухих речовин», а також зміну маси харчового продукту під час зберігання зважуванням досліджуваних зразків протягом місяця.

Для оцінки органолептичних властивостей зефіру 3 їстівним покриттям розроблено 5-балову шкалу. Методом ранжування було визначено коефіцієнти вагомості кожного показника в загальній органолептичній оцінці, що наведено в табл. 1.

\section{Таблиця 1. Балова оцінка якості зефіру}

\begin{tabular}{|c|c|c|c|}
\hline Показник & $\begin{array}{c}\text { Коефіцієнт } \\
\text { вагомості }\end{array}$ & Бали & Характеристика \\
\hline \multirow{5}{*}{$\begin{array}{c}\text { Зовнішній } \\
\text { вигляд: } \\
\text { форма }\end{array}$} & \multirow{5}{*}{0,1} & 5 & $\begin{array}{l}\text { Властива даному виду виробу, правильна, не м'ята, не } \\
\text { розпливчата }\end{array}$ \\
\hline & & 4 & Правильна, з легкими притисками \\
\hline & & 3 & Злегка прим'ята і розпливчаста \\
\hline & & 2 & Розпливчаста, з боковими випливами \\
\hline & & 1 & Неправильної форми, розпливчаста, прим’ята \\
\hline \multirow{5}{*}{ Поверхня } & \multirow{5}{*}{0,1} & 5 & $\begin{array}{l}\text { Без грубого затвердіння на бічних гранях, гладка або } \\
\text { злегка шорохувата } \\
\end{array}$ \\
\hline & & 4 & Гладка, шорохувата \\
\hline & & 3 & Гладка, з незначною зморшкуватістю \\
\hline & & 2 & Зморшкувата, помітне затвердіння на гранях \\
\hline & & 1 & Дуже тверда на бічних гранях \\
\hline \multirow{5}{*}{ Колір } & \multirow{5}{*}{0,1} & 5 & Рівномірний, білий із кермовим відтінком \\
\hline & & 4 & Повністю білий \\
\hline & & 3 & Нерівномірний колір з кермовим відтінком \\
\hline & & 2 & Нерівномірний колір з жовтим відтінком \\
\hline & & 1 & Нерівномірний колір з сіруватим відтінком \\
\hline \multirow{5}{*}{ Структура } & \multirow{5}{*}{0,1} & 5 & Рівномірна, еластична, не липка на дотик, дрібнопориста \\
\hline & & 4 & Рівномірна, еластична, дрібнопориста \\
\hline & & 3 & Рівномірна, нееластична, дрібнопориста \\
\hline & & 2 & Рівномірна, з великими порами \\
\hline & & 1 & Рівномірна, нееластична, трішки липка на дротик \\
\hline \multirow{5}{*}{ Смак і запах } & \multirow{5}{*}{0,2} & 5 & Характерний зефіру, добре виражений \\
\hline & & 4 & Виражений, характерний зефіру \\
\hline & & 3 & Недостатньо виражений, характерний зефіру \\
\hline & & 2 & Невиражений \\
\hline & & 1 & Невластивий, неприємний, посторонній \\
\hline \multirow{5}{*}{ Консистенція } & \multirow{5}{*}{0,1} & 5 & М'яка, легко піддатлива до розламування \\
\hline & & 4 & Злегка затяжна, піддатлива до розламування \\
\hline & & 3 & Злегка затяжна, ледь піддатлива до розламування \\
\hline & & 2 & М'яка, під час розламування середина виробу мокра \\
\hline & & 1 & Занадто м’яка, середина під часу розламування мокра \\
\hline \multirow{5}{*}{$\begin{array}{l}\text { Розжову- } \\
\text { ваність }\end{array}$} & \multirow{5}{*}{0,3} & 5 & Добре розжовується \\
\hline & & 4 & Розжовується з невеликим зусиллям \\
\hline & & 3 & Жорсткувата при розжовувані \\
\hline & & 2 & Жорстка \\
\hline & & 1 & Важко розжовується \\
\hline
\end{tabular}


Результати і обговорення. Їстівне покриття являє собою тонкий шар їстівного матеріалу, утвореного у вигляді покриття на харчовому продукті. Було розроблено їстівне покриття, яке складається з крохмалю, желатину та гліцерину. Вибір компонентів, які сформували їстівну плівку, обумовлений легкістю технологічного аспекту й органолептичним властивостями (нейтральний смак $\mathrm{i}$ запах, прозорість покриття, розжовуваність). Желатинове покриття зберігає краще вологу, ніж крохмаль, який здатен піддаватися ретроградації [8]. Поєднання желатину та крохмалю в основі їстівного покриття зумовлене тим, що желатин під час охолодження утворює желе, що унеможливлює подальше нанесення такого покриття на кондитерські вироби. Додавання желатину значно підвищує механічну міцність, розчинність у воді, паропроникність $\mathrm{i}$ товщину плівки. Всі обрані складові харчового покриття $є$ доступними та безпечними [9].

Їстівне покриття не повинне змінювати органолептичні показники зефіру. Проведено дегустацію на базі кафедри експертизи харчових продуктів Національного університету харчових технологій. Результати зведених дегустаційних оцінок і розрахунок загального показника якості їстівних покриттів наведено у табл. 2.

Таблиия 2. Зведені дегустаційні оцінки органолептичної оцінки якості досліджуваних зразків зефіру

\begin{tabular}{|c|c|c|c|c|c|c|c|c|}
\hline & Форма & Поверхня & Колір & Структура & $\begin{array}{c}\text { Смак і } \\
\text { запах }\end{array}$ & $\begin{array}{c}\text { Консис- } \\
\text { тенція }\end{array}$ & $\begin{array}{c}\text { Розжову- } \\
\text { ваність }\end{array}$ & $\begin{array}{c}\text { Уза- } \\
\text { галь- } \\
\text { нений } \\
\text { Зразок }\end{array}$ \\
\cline { 2 - 9 } & 0,1 & 0,1 & 0,1 & 0,1 & 0,2 & 0,1 & 0,3 & $\begin{array}{c}\text { показ- } \\
\text { ник } \\
\text { якості }\end{array}$ \\
\hline $\begin{array}{c}\text { Зразок в } \\
\text { упаковці }\end{array}$ & $4,8 \pm 0,1$ & $4,8 \pm 0,1$ & $4,9 \pm 0,1$ & $5,0 \pm 0,2$ & $5,0 \pm 0,2$ & $4,8 \pm 0,1$ & $4,8 \pm 0,1$ & 4,87 \\
\hline $\begin{array}{c}\text { Зразок без } \\
\text { порошку }\end{array}$ & $4,8 \pm 0,1$ & $4,8 \pm 0,1$ & $4,9 \pm 0,1$ & $5,0 \pm 0,2$ & $5,0 \pm 0,2$ & $4,8 \pm 0,1$ & $4,9 \pm 0,1$ & 4,90 \\
\hline Зразок 1 & $4,8 \pm 0,1$ & $4,9 \pm 0,1$ & $5,0 \pm 0,1$ & $5,0 \pm 0,2$ & $5,0 \pm 0,2$ & $4,8 \pm 0,1$ & $4,9 \pm 0,1$ & 4,92 \\
\hline Зразок 2 & $4,8 \pm 0,1$ & $4,9 \pm 0,1$ & $4,9 \pm 0,1$ & $5,0 \pm 0,2$ & $5,0 \pm 0,2$ & $4,8 \pm 0,2$ & $4,9 \pm 0,1$ & 4,91 \\
\hline Зразок 3 & $4,8 \pm 0,1$ & $4,8 \pm 0,1$ & $5,0 \pm 0,1$ & $5,0 \pm 0,2$ & $5,0 \pm 0,2$ & $4,8 \pm 0,2$ & $4,9 \pm 0,1$ & 4,91 \\
\hline
\end{tabular}

Примітка: Зразок 1 - зефір з чорничним порошком, зразок 2 - зефір з полуничним порошком, зразок 3 - зефір з лимонним порошком.

Органолептична оцінка якості досліджуваних зразків зефіру показала, що розроблене їстівне покриття не змінює органолептичні показники.

Досліджено зміну фізико-хімічних показників шляхом визначення зміни масової частки вологи в зефірі під час зберігання, оскільки процеси десорбції $\epsilon$ процесами, які призводять до виділення вологи та усихання зефіру. Результати зміни масової частки вологи зразків зефіру під час зберігання наведено на рис. 1.

Відповідно до рис. 1 у зефірі без упаковки швидко зменшується вологість порівняно із зефіром з їстівним покриттям, у якому вона зменшується значно повільніше. Вологість зефіру в упаковці та їстівному покритті практично однакові. Через місяць зберігання зразків вологість зефіру без упаковки 
зменшилась на 44\%, а зефіру з їстівним покриттям - на 30\%. Отже, їстівне покриття має бар'єрні властивості, що сприяє більш тривалому збереженню зефipy.

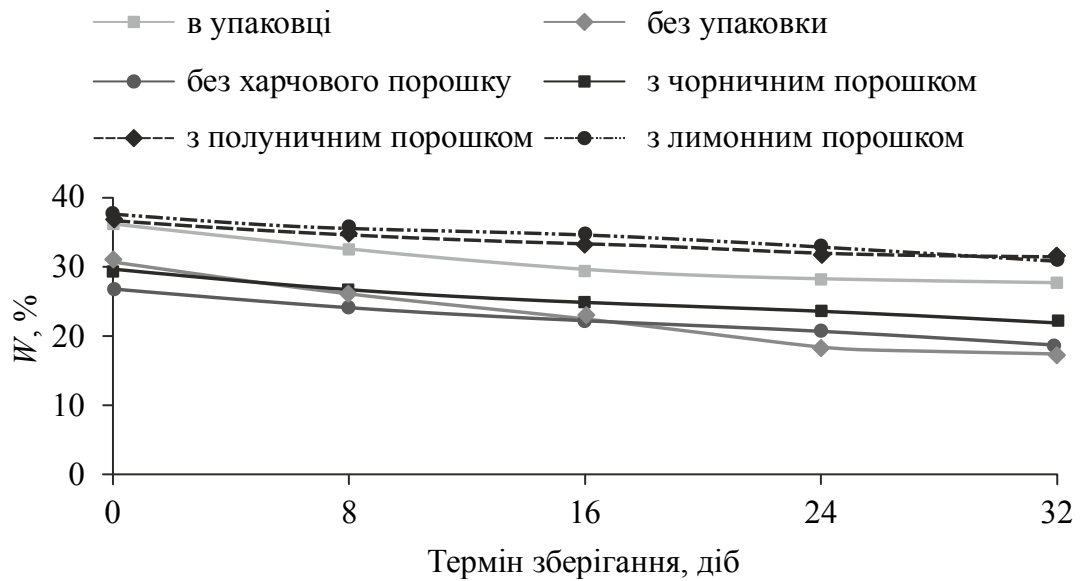

Рис. 1. Зміна масової частки вологи зразків зефіру під час зберігання

Досліджено зміну маси зразків зефіру під час зберігання. Результати наведено на рис. 2.

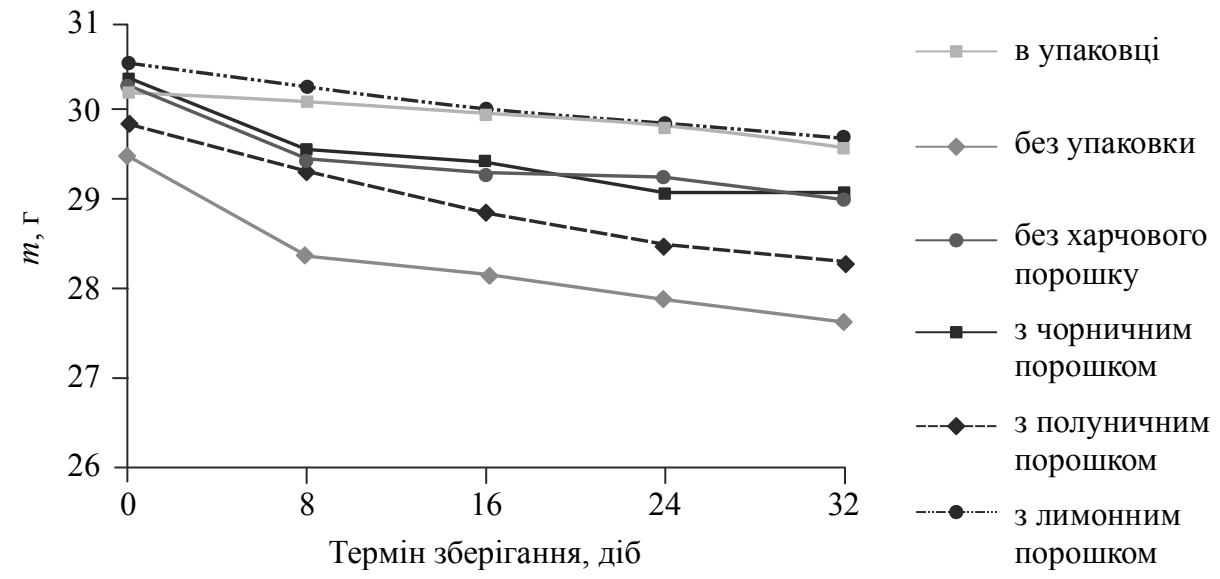

Рис. 2. Зміна маси зразків зефіру впродовж зберігання

Встановлено, що під час зберігання зефіру протягом місяця маса продукту без упаковки зменшується на $6,3 \%$, зефір з їстівним покриттям зменшив свою масу на 4,3\%. Найгірше зберігає свої властивості зефір без упаковки, що зумовлено відкритим доступом повітря до харчового продукту, найкраще зефір 3 їстівним покриттям 3 лимонним порошком. Згідно з результатами досліджень, можна припустити, що їстівне покриття та зберігання продукту в упаковці ідентичні за значеннями, а зефір з їстівним покриттям без додавання порошку та 3 чорничним порошком мають подібні результати відхилень маси. Проте зефір з додаванням полуничного порошку не призначений для тривалого збереження. 


\section{Висновки}

Отже, їстівні плівки та покриття, що застосовуються для харчових продуктів, є ефективними матеріалами для збільшення терміну зберігання продукції. При цьому мікробіологічні, органолептичні, фізико-хімічні показники та споживні характеристики майже не змінюються. У їстівних плівкоутворюючих покриттях найбільш важливими властивостями $€$ їх мікробіологічна стабільність, адгезія, когезія, змочуваність, розчинність, прозорість, механічні властивості, проникність для водяної пари та газів.

У результаті досліджень маса і масова частка вологи зефіру зменшується більше без упаковки, ніж з їстівним покриттям. Найкраще зберігає свої властивості зефір з їстівним покриттям 3 додаванням лимонного порошку, найгірше - зефір з їстівним покриттям 3 додаванням полуничного порошку. Можливо, більші втрати маси були зумовлені недостатньо щільним шаром нанесення їстівного покриття. Враховуючи вищесказане, можна стверджувати, що їстівне покриття сприяє збереженню свіжості зефіру і $є$ альтернативною заміною (частковою або повною) синтетичного пакування.

\section{Література}

1. Асортимент пастильних виробів [Електронний ресурс]. — Режим доступу : http:// studfiles.net/preview/5424431/page:3/.

2. Фруктово-ягідні кондитерські вироби [Електронний ресурс]. - Режим доступу : https://studfiles.net/preview/5193694/page:13/.

3. Зефір [Електронний ресурс]. — Режим доступу : http://fullukrmed.ru/rizne/15774zefir.html.

4. Pavlath A.E. Edible Films and Coating: Why, What and How? / A.E. Pavlath, W. Orts // Edible Films and Coatings for Food Applications / M. Embuscado, K.C. Huber. - Springer, 2009. - P. 1. - C. $1-25$.

5. Edible coatings and films to improve food quality / J.M. Krochta, E.A. Baldwin, M.N. Carriedo. — CRC Reprint, 2002. - P. 97-98.

6. Снежко А.Г. Новые упаковочные материалы и перспективы их использования / А.Г. Снежко, А.В. Федотова, Е.А. Евстафьева // Пищевая индустрия. — 2008. — № 8. C. $20-21$.

7. Perez-Gago M.B. Protein-Based Films and Coatings Gennadios / M.B. Perez-Gago, J.M. Krochta. - CRC Press, Boca Raton, FL, 2002. - P. 159-180.

8. Товарознавство кондитерських виробів [Електронний ресурс]. - Режим доступу : http://pidruchniki.com/12700917/.

9. Гліцерин [Електронний ресурс]. - Режим доступу : http://sistema-optimum.chezukrayina.business-guide.com.ua/products/unit?pid=212265. 